\title{
Investigating mass customization and sustainability compatibilities
}

\author{
K. Medini ${ }^{1 *}$, J. Le Duigou ${ }^{2}$, C. Da Cunha ${ }^{3}$, A. Bernard ${ }^{3}$ \\ ${ }^{1 *}$ Ecole Nationale Supérieure des Mines de Saint Etienne, 158 Cours Fauriel, Saint Etienne, FRANCE \\ ${ }^{2}$ Université de Technologie de Compiègne, Laboratoire Roberval UMR CNRS 7337, Rue du Docteur Schweitzer, 60203 Compiègne, FRANCE \\ ${ }^{3}$ LUNAM Université, Ecole Centrale de Nantes, IRCCyN UMR CNRS 6597, 1 Rue de la Noë, Nantes, FRANCE \\ "Corresponding Author: e-mail: khaled.medini@emse.fr.Tel. +334774293 17, Fax.+33477426633
}

\begin{abstract}
This paper examines the relationships between sustainability and mass customization in the business field. First a literature review investigates their enablers. This section ends with empirical conclusions about the impact of mass customization on sustainability highlighting some complementarities between these two concepts. Then three case studies illustrate the relevance of the identified enablers to different business sectors. The case studies show that several sustainability and mass customization enablers are deployed within same industrial contexts, thus pointing out potential synergies between them. The lack of sustainability and mass customization frameworks at the operational level is a major barrier for further investigation of the above synergies.
\end{abstract}

Keywords: Mass customisation, sustainability, enablers, sustainable mass customisation.

DOI: http://dx.doi.org/10.4314/ijest.v7i1.2

\section{Introduction}

Companies are endeavouring to survive competition from emergent markets and cope with the tough regulations related to sustainability. Accordingly strategies such as mass customization gained a lot of interest among academicians and practitioners (Fogliatto et al., 2012). Furthermore, new practices and tools are emerging under the umbrella of sustainability, such as sustainable manufacturing, eco-design and closed loop supply chains (Kleindorfer et al., 2005). The Brundtland Commission viewed sustainable development as meeting "the needs of the present without compromising the ability of future generations to meet their own needs" (WCED, 1987). Therefore, the challenge for enterprises is to generate profit while preserving the environment and ethically managing labour and promoting their surrounding communities.

Mass customisation (MC) is a paradigm first introduced by Davis in 1987 (Davis, 1987). Pine (1993) and Tseng and Jiao (2011) defined MC as "producing goods and services to meet individual customer needs with near mass production efficiency". MC is a compromise between pure customisation and mass production, between individualism and efficiency, between variety and complexity (Daaboul et al., 2011). Mass customization entails some aspects leveraging companies' sustainability (Jovane et al., 2008; Bettoni et al., 2013; Boër et al., 2013). However there is still a debate on whether mass customization really fosters sustainability regarded as a crossing of economic, environmental, and social dimensions. In fact, many academicians advocate a positive impact of mass customization on sustainability while practitioners generally think that these concepts have only minor mutual impacts (Pourabdollahian et al., 2014). Consequently the synergy between these concepts is still an open question which if answered, could help companies improving their sustainability impact along with customer satisfaction through mass customization. The empirical research presented in this paper aims to identify synergies between mass customization and sustainability. To do so, literature is reviewed for enablers of mass customization and sustainability. The relevance of these enablers is checked in three different business sectors with the aim to identify synergies between the above concepts.

The remainder of the paper is organized as follows; sections 2 and 3 identify enablers of mass customization and sustainability at operational level, through literature review. Afterwards, three case studies are presented and discussed in section 3 , in order to 
illustrate the applicability of the identified enablers in industrial context. Section 4 discusses the synergies between sustainability and mass customization. The paper ends with concluding remarks and prospects in section 4.

\section{State of the art}

Mass customization and sustainability literatures are prolific; they are addressed from different points of view such as typologies, evaluation and deployment. In this section, we will focus on the last point of view, more specifically how to deploy sustainability and mass customization in the business field. The aim is to identify main enablers of these concepts and analyze the synergies between them. Accordingly, following points are discussed, enabling mass customization, enabling sustainability in the business field and finally mass customization impact on sustainability.

2.1 Enabling mass customization: According to Da Silveira et al. (2001) there are 6 main mass customization success factors: (1) Customer demand for variety and customization must exist, (2) market conditions must be appropriate, (3) value chains should be ready, (4) technology must be available, (5) products should be customizable, and (6) knowledge must be shared. Customer demand for variety and market conditions are strategic and tactical enablers. Conversely, product design and knowledge sharing, manufacturing technologies, and value chain optimization, can be investigated as operational enablers. Authors such as Tseng et al. (1996) promoted the concept of designing for mass customization (DMC). One aim of DMC is the optimisation of product complexity with respect to customer preferences. In fact, there is an optimum between customer satisfaction adding customized features and product complexity (Blecker et al., 2006; Jiao et al., 2007; Daaboul et al., 2011).

Standardization, modularity, and commonality are among the main MC enablers (Pine, 1993; Fogliatto et al., 2012). They lower MC costs through economy of scale and reduced inventories, and improve the forecasting of component needs. In order to accommodate as much commonality and standardization as possible, product platforms can be used (Jiao et al., 2007). A product family is "a group of similar products that are derived from a common platform but each having specific features/ functionalities in order to satisfy particular customer requirements" (Meyer and Lehnerd, 1997). Information and Communication Technologies (ICTs) also play an important role in product design, first as change management support, such as product platforms (Jiao et al., 2007) and as customer relationship enablers (Smith et al., 2013), as MC Information Systems. An example of how customized products are built based on product family and how parametric CAD can manage their related information can be found in (Le Duigou et al., 2011). Moreover, a product configurator is essential for a successful MC in many senses: storing customer related data, estimating costs (Tseng and Piller, 2003), customizing the product, generating technical artefacts (Tseng and Piller, 2003; Roach et al., 2011), transferring data checking design feasibility, and for 3D product visualization (Sievaanen and Peltonen, 2006; Cross et al., 2009). The design for MC includes not only the product, but also manufacturing systems and supply chains (Jiao et al., 2004; Shahzad and Hadj-Hamou, 2013).

The manufacturing system is the second key domain for mass customisation enablers. Authors such as Fogliatto et al. (2012) pointed out agile manufacturing, supply chain management, lean manufacturing and customer driven design and manufacturing as the main enablers of MC. As highlighted by Fogliatto et al. (2012) and Smith et al. (2013) the flexibility of the manufacturing system is one of the key success factors of mass customization. Process standardization is an MC enabler: it reduces the production lead time and enables process costs. Automating technology is also needed to enhance standardization (Selladurai, 2004). A modularized manufacturing system (Smith et al., 2013) can also reduce lead time and cost with only a few changes on the workbenches to reconfigure the production line between product batches. For instance, Qiao et al. (2006) proposed a modularized production line with movable and reconfigurable workbenches, and flexible transportation equipment. Another example of a modularized manufacturing system is that of the mobiCells of BMW which relies on standardisation, modularity and reconfigurability (Mortimer, 2007). Duray (2006) has proven that strong worker flexibility and teamwork improve the performance of a manufacturing system in an MC context. Minimizing operation costs turns out to be a major enabler of mass customization (Pine, 1993; Selladurai, 2004). By reducing operation costs the customized product may be offered at a price similar to that of mass production. Finally, ICTs and Advanced Manufacturing Technologies enable more efficient management of all connected data, an example of these are Computer Aided Process Platforms (Da Silveira et al., 2011; Jiao et al., 2007).

Mass customization can be leveraged also through enablers at the supply chain level. A supply chain consists of all parties involved, directly or indirectly, in fulfilling a customer demand (Chopra and Meindl, 2007). In a mass customization context, Da Silveira et al. (2001) and Fogliatto et al. (2012) consider that the supply chain must be agile, which requires a high delivery service, an active collaboration of suppliers in product design and an effective communication with them through interconnected information systems. Dietrich et al. (2006) also advocate that coordination between different players in the supply chain is the main success factor for MC. In this regard supply chain management is the key success factor of mass customization (Smith et al., 2013).

2.2 Enabling sustainability in the business field: Most of the environmental impacts of products, throughout their life cycle, are determined at the design phase (UNEP, 2009). Thus concepts and methods such as Design for Recycling or Design for Environment, and Design for Sustainability in general have come to the fore (Garbie, 2013). Their aim is to reduce material and energy consumption and waste throughout the product life cycle. The integration of sustainability in the design process has been 
reinforced by the use of sustainability assessment tools such as Life Cycle Assessment (LCA). LCA aims to integrate environmental considerations into product design (Knight and Jenkins, 2009). The assessment is used to guide the designer in evaluating different product alternatives with the same functional unit (i.e. amount of the product to consider during the assessment). The evaluation of the product at design phase can be qualitative (e.g. questionnaires), semi qualitative (e.g. analysis grids) or quantitative (i.e. pure LCA with direct data collection or use of LCA data basis).

At manufacturing system level, new practices have emerged such as sustainable or green manufacturing. Reducing hazardous emissions, eliminating waste, reducing resource consumption and recycling are examples of green manufacturing activities (Fortes, 2009; Gunasekaran and Spalanzani, 2011; Medini et al., 2012). Green manufacturing is closely linked to waste management through the elimination of causal factors. In this way, green manufacturing can be seen as close to Lean manufacturing principles (Kleindorfer et al., 2005). Regarding the social dimension of sustainability, Dreyer et al. (2010) highlighted the role of establishing guidelines and practices and the importance of the commitment to efficiently record and communicate data regarding labour rights.

At supply chain level new environmentally friendly practices have emerged under the umbrella of Sustainable Supply Chain Management (sSCM). This latter integrates sustainable considerations into supply chain policies, programs and actions (Large and Thomsen, 2011). SCM can be defined as "the process of managing the SCM activities with consideration for environmental, economic and social issues for enhancing the long term economic goals of an individual organization and its supply chains" (Al Odeh and Smallwood, 2012). The objective of a sustainable supply chain is to facilitate recycling, reuse and resource reduction and taking social and economic considerations into account (Carter and Carter, 1998). One of the widely discussed forms of sSCM is closed loop supply chains which provide a framework for the 6R approach: reduce, reuse, recover, redesign, remanufacture, and recycle (Jayal et al., 2010).

2.3 Mass customization impacts on sustainability: Table 1 shows a sum up of mass customization and sustainability enablers appearing in literature. According to Jovane et al. (2008), mass customization reduces the unsold items by a make-to-order business model principle. It reduces resources and energy use and induces a better understanding and satisfaction of the customer. In other words, a customized product is supposed to fit specific customer needs (Brunoe et al., 2014). It can be argued that agility and lean practices, which are key elements of mass customization, have a positive impact on cost, lead time and environmental performance (i.e. profit and planet parts of the triple bottom line (Elkington, 1997)).

Table 1. Mass Customization and sustainability enablers appearing in literature

\begin{tabular}{|l|c|c|}
\hline Enabler & Mass customization & Sustainability \\
\hline Design for MC & $\mathrm{X}$ & \\
\hline Modularity & $\mathrm{X}$ & \\
\hline Standardization & $\mathrm{X}$ & \\
\hline ICTs / Product Configurator & $\mathrm{X}$ & $\mathrm{X}$ \\
\hline Eco-design & & $\mathrm{X}$ \\
\hline Cost reduction & $\mathrm{X}$ & $\mathrm{X}$ \\
\hline Reliability & $\mathrm{X}$ & $\mathrm{X}$ \\
\hline Agile manufacturing & $\mathrm{X}$ & $\mathrm{X}$ \\
\hline Lean manufacturing & $\mathrm{X}$ & \\
\hline Automation & $\mathrm{X}$ & \\
\hline Customer involvement & $\mathrm{X}$ & \\
\hline Innovative Process Technologies & $\mathrm{X}$ & \\
\hline Reducing operations cost & $\mathrm{X}$ & $\mathrm{X}$ \\
\hline Modular processes & $\mathrm{X}$ & $\mathrm{X}$ \\
\hline Strong workforce practices of teamwork & & $\mathrm{X}$ \\
\hline Worker flexibility & & $\mathrm{X}$ \\
\hline Sustainable manufacturing & & $\mathrm{X}$ \\
\hline Waste management & & $\mathrm{X}$ \\
\hline Cost reduction & & $\mathrm{X}$ \\
\hline Labour management & $\mathrm{X}$ & $\mathrm{X}$ \\
\hline Social development & $\mathrm{X}$ & \\
\hline Green, affordable and secure technologies & & $\mathrm{X}$ \\
\hline Supply chain coordination & & \\
\hline Agile supply chain & & \\
\hline Reverse logistics & & \\
\hline Cost reduction & & \\
\hline Supplier selection & & \\
\hline & & \\
\hline
\end{tabular}


Automation, occurring in mass customizing production systems, leads to shorter lead times and may reduce costs if savings generated overcome initial investments in automating equipment. Furthermore, modular product design as an enabler of mass customization has a positive impact on product recovery at its end-of-life (Krikke et al., 2003). Conversely, the processes delivering modular products require typically more energy and material consumption (Brunoe et al., 2014). Moreover, mass customization may lead to even more environmental impact than mass production. For instance, in mass customization, the orders delivery is not often optimised since every order is delivered individually to a specific customer. This leads to more greenhouse gases emissions and energy consumption, according to the used mean of transport.

An empirical research made by Pourabdollahian et al. (2014) showed that there is no consensus on mass customization impact on environmental sustainability. It also highlighted some interesting findings related to academicians and industrials perceptions of the synergies between mass customization and sustainability. In fact, the complementarities between these paradigm is typically advocated by researchers, while industrials think there is often no direct impact of mass customization enablers on sustainability. This means that cases studies based research is required to investigate such an impact. This helps drawing conclusions based on industrial context rather than more theoretical models. After providing a theoretical background in the current section, three case studies are presented in the following section. The aim is the check how mass customization and sustainability enablers are deployed within same industrial contexts.

\section{Case studies}

3.1 Empirical research method: First, we present sustainable mass customization related objectives and main performance indicators that the company wants to improve. Objectives and indicators are identified through interviews with companies' CEOs. Interviewees are guided by questions about mass customization strategy, sustainability practices and performance evaluation. Then, we analyse companies' current business processes upon modelling them using IDEF0. These are a series of techniques to analyse production systems whose central concept is the function (NIST, 1993). The necessary data for the modelling is collected from internal reports and face-to-face meetings with production and management staff. The modelling is validated by company management. The analysis of companies' business processes helps identifying, along with the case company, required enablers and enablers that are actually being put in practice to move forwards to sustainability and mass customization. The above method is applied to three SMEs from different business sectors namely kitchen furniture, tanning and footwear, and stone cutting tools.

3.2 Case A - kitchens manufacturer: Company A is a kitchen manufacturer specialised in luxury customized kitchens with a high associated cost. The company started investing consistently on new technologies since few years, when 5 new production machines were bought. These new machines are the basis for the upgrade and enhancement of product customization and Just in Time production. Products are divided in Kitchen product lines, from basic lines to top quality lines. At the moment they have more than 14 product lines. It also produces cupboards, wardrobes, cabinets, bookcases, columns and bookshelves of any dimension. Accordingly, one of the main differences between company A and most of its competitors, is that the latter usually order the furniture/cabinets from the main producer and they can usually get only standard sizes, while the case company A can produce furniture with any dimension/size and can therefore better fulfil individual requirements.

However, being in a competitive environment, there is continuous pressure to produce more effectively and improve its environmental performance. Company A's strategy is to facilitate the customization experience for the customers while reducing costs, delivery times, and improving social and environmental performances. The customization of the kitchen is carried out by the retailer based on customer requirements to provide a draft kitchen. This is sent to the designer who updates it and transfers it to the production department. Production is then planned and launched upon reception of raw materials and components (handles, hinges, boards, appliances, etc.). The kitchen is packaged and then delivered by a logistics partner (Figure 1). Time is a major concern for the manager who "cannot let customers wait"; lead time has then to be reduced. Time consuming operations are mainly: customisation of a kitchen, exchanges of data between the retailers and the factory, materials delivery time, and production time.

To improve costs, delivery time, and social performance, potential improvements are associated to the collaboration/coordination with the customer, the collaboration/coordination with suppliers and to the internal manufacturing processes. Intense cooperation between the company and its customers is needed. Retailers should provide more guidance to customers through the customization operation. This reduces time needed for the customer to define and update his chosen kitchen design, offering him better customization experience. Subsequent kitchens draws should be automatically transferred to the designer in charge of checking and validating them. Customers' orders are going to be automatically transferred between design and production departments, through a newly developed orders automation system. This smooth integration of company tools (ERP, CADs, etc.) improves, in particular, the customization level and customization time. Although company A maintains long term relationships with its suppliers, the collaboration terms need to evolve after the introduction of environmental and economic sustainability related criteria in evaluating the suppliers' offers. For example, minimal lot size (i.e. lower inventory level), use of sustainable raw materials for the kitchen cabinet panels, delivery time, etc. Accordingly, company A needs to redefine the collaboration terms with its suppliers. This change is crucial, since the suppliers' performance will impact the ability of the company to deliver the mass customized kitchen in a shorter time, while reducing the internal costs related to inventory levels and offering a more sustainable product. 
The internal manufacturing processes fail short of supporting a flexible manufacturing system. Hence, current cutting machines are going to be replaced by a NC machine. In addition, the edge of the panels is currently stuck using glue, this is less efficient than the new proposed one using laser. Subsequent enablers identified in case company A are as follows:

- Automated kitchen draws

- Coordination/communication between resellers and designers

- Improve the customer experience: reduce the delay of verifying/ approving the feasibility of the chosen design

- Improve the product design process and use more sustainable raw materials

- Reinforce process flexibility by using advanced manufacturing technologies (NC machine)

- Reduce inventory level

- Reduce replenishment lead time

- Reduce lot size

- Consider sustainability criteria in suppliers evaluation

3.3 Case B - tanner: Company B is in footwear industry. It aims to gain new market shares by proposing customized leather skins with small lot size in a short period of time. Company B produces an extensive range of shoes for customers of different ages and for different daily activities: classic designs and designs for the leisure time, for women, men, adult and young. Main supplier of company B is a local tannery providing medium priced high quality leader. It is all produced in-house, mainly from raw. Processing is fully integrated and automated and a huge investment has been made not only in practically doubling the size of the tannery but in also continuing to upgrade the automation.

Shoes are designed according to customer trends. The production is planned and if the raw material in particular, leather, is available, production is launched. Finally, shoes are transported to resellers where final customers buy them (Figure 2). The poor coordination between designers and other supply chain actors limits customization options. Moreover, customer order processing is often constrained by the availability of the required leather. To shift to a real mass customization oriented production, more collaboration is required between all the supply chain actors and the final customers. Designers need to collaborate with retailers to identify customer expectations and translate them into feasible designs, respecting the manufacturing system capacity. A more sophisticated information system collecting customer related data might be used for this purpose.

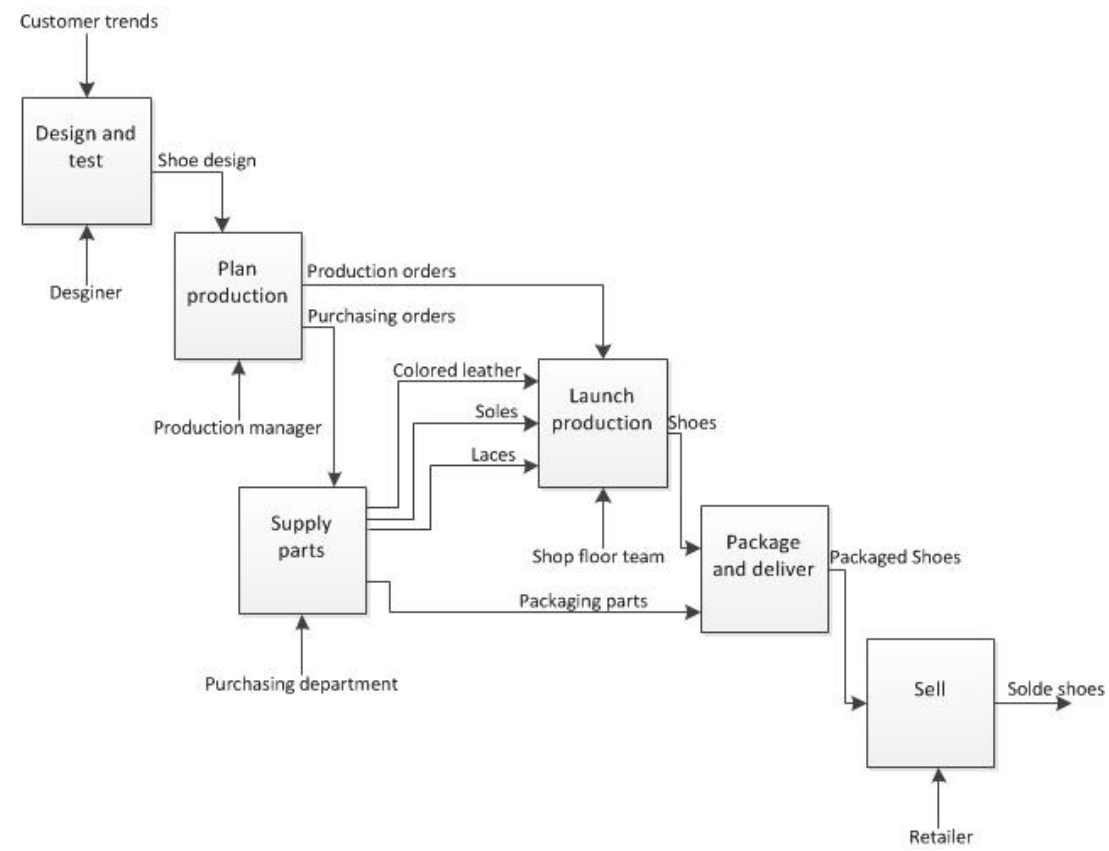

Figure 1. Case A as-is business processes modelling

A new tanning technology (BCD - Dried Collagen Biomaterial) is being introduced. It helps to dramatically reduce lead times, inventory levels and lot sizes because leather can be easily transported, stored and used in shoe production lines (dry instead of being wet). There is a potential gain of water consumption through the use of this technology that provides a closed loop circuit for water use.

To sum up, required enablers for implementing a sustainable mass customization in company B are as follows:

- Reinforce customer involvement 
- New manufacturing technologies (tanning technologies, etc.)

- Reduce inventory level

- Reduce lead time

- Reduce water consumption and waste

- Reinforce coordination between designers and SC actors

- Reduce replenishment lead time

3.4 Case C - stone cutting tools manufacturer: Company $\mathrm{C}$ is a stone cutting tools manufacturer. It aims to propose more customized products and adapt its offer to customers' specific applications. The company's aspirations are focused on economic and environmental dimensions of sustainability. The product line considered within this study is a diamond wire which is the main product of the case company. The production of wire-rod follows the common use criteria of Make-To-Order production. Company $\mathrm{C}$ produces different typologies of wire-rod in order to be ready for any kind of customer request. A story of past sales offers a firm base for a forecast of future customer needs and requests. The wire specifications are defined according to customer needs. Parts are supplied, and then beads (main part of the wire) are produced. Production process parameters (e.g. bead powder mix, etc.) determine the physical properties of the beads. The wire is then assembled and delivered to customers (quarries) (Figure $3)$.

The design process is based on the company's experience in the field of stone cutting tools. Once a prototype is produced and validated, the manufacturing process is launched. In order to better satisfy customer requirements, the company's knowledge needs to be capitalized, in particular data regarding cutting parameters and cutting conditions (type of stone, etc.). These data are recorded in the cutting machine using the diamond wire. It helps to define more suitable tools (i.e. diamond wires) to customer specific applications, which will improve the supply chain agility.

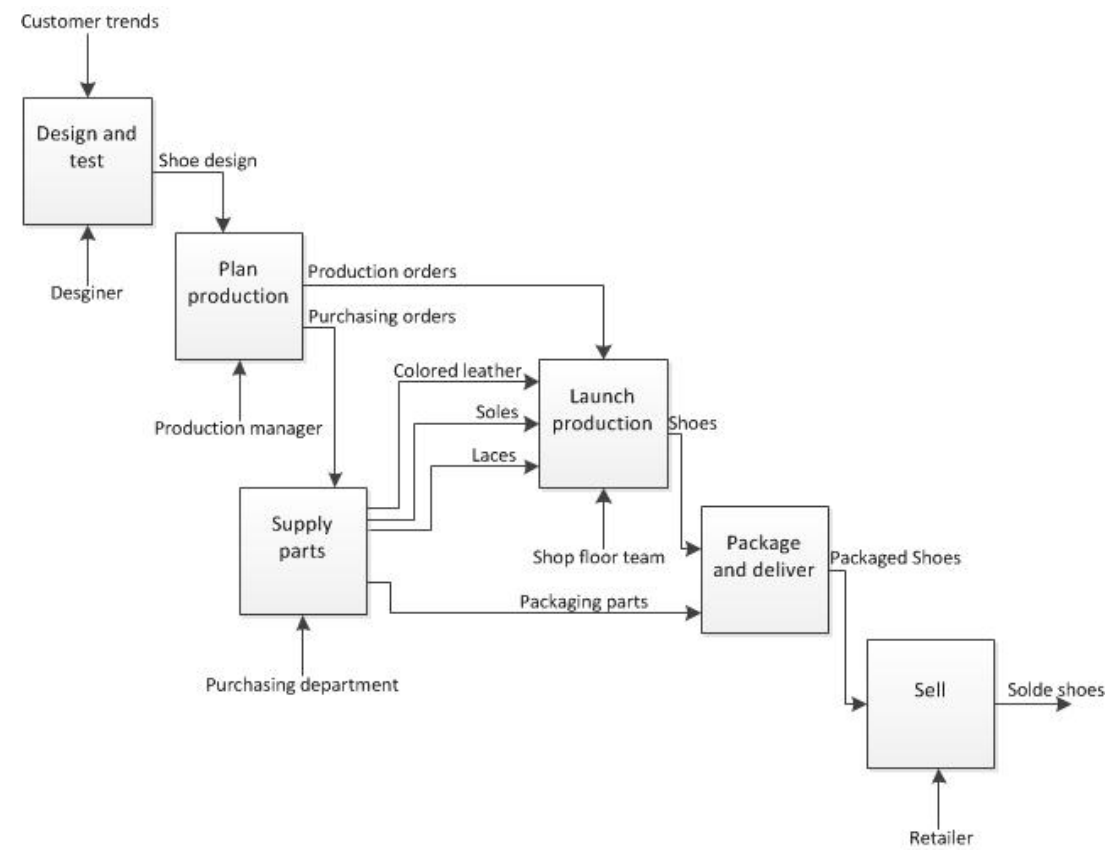

Figure 2. Case B as-is business processes modelling

Personalized mixtures will enable the manufacturing of customized beads and the production of specific diamond wire for particular technologies or requirements. This suggests modifications of the process planning of tool components and reduces its environmental impact at production (i.e. production processes) and use phases (i.e. product). Extracted enablers from case company $\mathrm{C}$ are as follows:

- Use raw material more efficiently

- Reduce water consumption and waste

- Knowledge management

- Improve agility

3.5 Enablers deployment: The case studies provide practical requirements to jointly shift to mass customization and sustainability. Each of the three cases presents a different industrial sector, which broadens the area explored to identify sustainability and mass 
customization enablers. In order to show how the extracted enablers are put into practice, they are mapped to the tools being actually deployed within the three case companies (S-MC-S consortium, 2011) (Table 2). These tools are not intended to provide a reference toolkit for implementing sustainable mass customization. However, our study illustrates their applicability to SMEs from three manufacturing sectors.

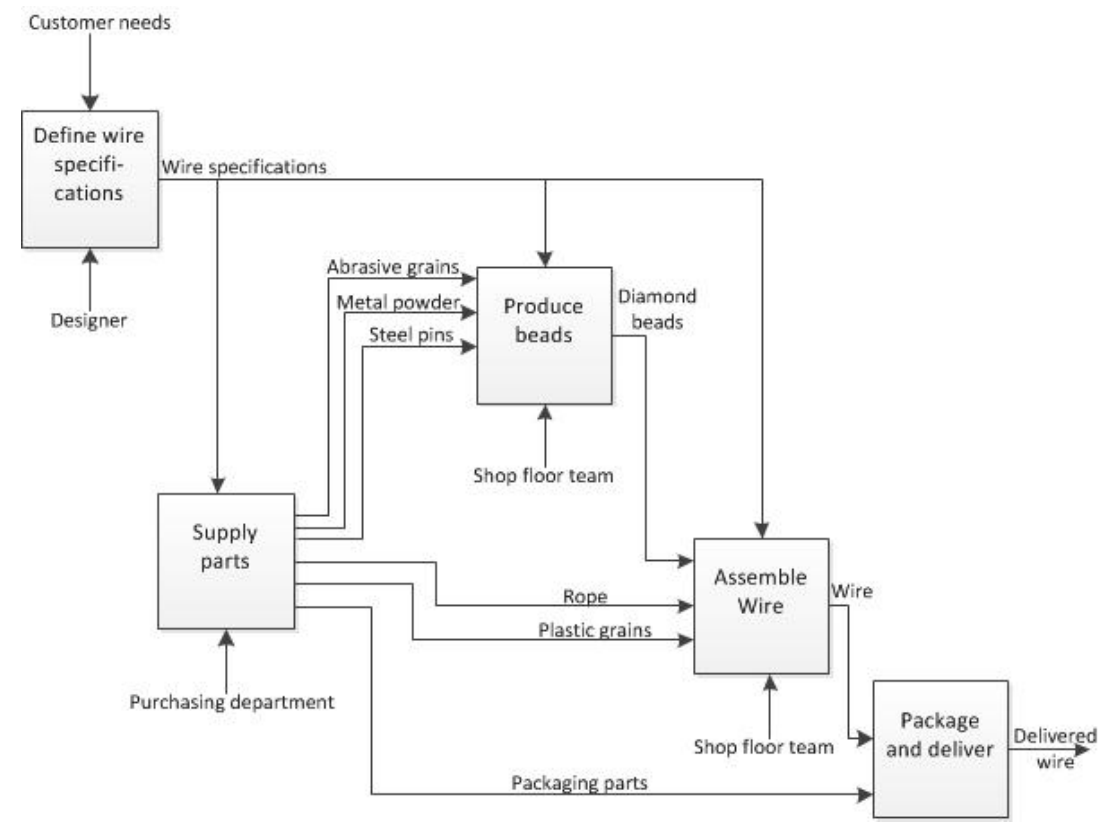

Figure 3. Case $\mathrm{C}$ as-is business process modelling

Sustainable mass customization design and assessment tools help reduce the use of resources and improve customization level. They also contribute to the reduction of lead time and reinforcement of customer involvement. In this regard, the assessment tool enables the evaluation of customer choices against sustainability metrics, hence pushing forward sustainable mass customization.

Table 2. Extracted enablers and operational tools

\begin{tabular}{|c|c|c|c|c|c|c|c|}
\hline \multirow[b]{2}{*}{ Enablers } & \multicolumn{7}{|c|}{ Tools } \\
\hline & $\begin{array}{l}\text { Design } \\
\text { tools }\end{array}$ & $\begin{array}{l}\text { Assessmen } \\
t \text { tool }\end{array}$ & $\begin{array}{c}\text { Dehydrati } \\
\text { on/ } \\
\text { degreasing } \\
\text { technology }\end{array}$ & $\begin{array}{c}\text { Waste } \\
\text { water free } \\
\text { continuous } \\
\text { flow process }\end{array}$ & $\begin{array}{l}\text { Customize } \\
\text { d Diamond- } \\
\text { Wire } \\
\text { technology }\end{array}$ & $\begin{array}{c}\text { Custom } \\
\text { ers order } \\
\text { automation } \\
\text { system }\end{array}$ & \begin{tabular}{|c|} 
New \\
sustainability and \\
mass \\
customization \\
Business model
\end{tabular} \\
\hline Reduce the delay of approving a customized design & $\mathrm{X}$ & $\mathrm{X}$ & & & & & $\mathrm{X}$ \\
\hline Reinforce customer involvement & $\mathrm{X}$ & $\mathrm{X}$ & & & & & $\mathrm{X}$ \\
\hline Knowledge Management & $\mathrm{X}$ & & & & & & $\mathrm{X}$ \\
\hline \begin{tabular}{|l}
$\begin{array}{l}\text { Improve the product design process: taking } \\
\text { environmental performance into consideration }\end{array}$ \\
\end{tabular} & $\mathrm{X}$ & $\mathrm{X}$ & & & & & $\mathrm{X}$ \\
\hline Use more sustainable raw materials & $\mathrm{X}$ & $X$ & & & & & $\mathrm{X}$ \\
\hline Reinforce processes flexibility & & & $\mathrm{X}$ & $\mathrm{X}$ & $\mathrm{X}$ & & $\mathrm{X}$ \\
\hline Reduce replenishment lead time & & & $\mathrm{X}$ & & $\mathrm{X}$ & $\mathrm{X}$ & \\
\hline Reduce lot size & & & $\mathrm{X}$ & $\mathrm{X}$ & & $\mathrm{X}$ & \\
\hline Reduce inventory level & & & $\mathrm{X}$ & & $\mathrm{X}$ & $\mathrm{X}$ & \\
\hline Reduce water consumption and wastes & & & $\mathrm{X}$ & $\mathrm{X}$ & & & \\
\hline Use raw material more efficiently & $\mathrm{X}$ & & $\mathrm{X}$ & $\mathrm{X}$ & & & $\mathrm{X}$ \\
\hline Develop new types of contracts with suppliers & & & & & & $\mathrm{X}$ & $\mathrm{X}$ \\
\hline Reinforce coordination between designers and SC actors & & & & & & $\mathrm{X}$ & $\mathrm{X}$ \\
\hline Improve agility & & & $\mathrm{X}$ & & & $\mathrm{X}$ & \\
\hline $\begin{array}{l}\text { Select suppliers while considering their environmental } \\
\text { performance as well }\end{array}$ & & & & & & $\mathrm{X}$ & $\mathrm{X}$ \\
\hline
\end{tabular}

The dehydration/degreasing technology applied in the leather sector enables the leather to be manipulated in a dry state. It facilitates the supply, storage and customization of the leather before selling it. It leads to a reduction in inventory level, tanning process lead time and improves flexibility. Such a technology also reduces water use. The waste water free continuous flow process and the Customized Diamond Wire technology also reduce water consumption. Furthermore, Customized Diamond 
Wire improves customization level, supply chain agility and customer involvement by fitting diamond wires to customer requirements collected during the use phase of the cutting tools. Customers order automation system integrates the different customer order management functions ranging from reception until delivery of the customized kitchen leading to more flexibility, more efficient inventory management policies, and better supply chain management. A novel business model coupling sustainability and mass customization comes to translate the SMC paradigm in a practical industrial way. It impacts the extracted enablers either directly or indirectly by defining a set of alternatives and supporting tools to implement a sustainable mass customization.

\section{Discussions}

The extracted enablers are in line with those identified in literature. The three case studies also show that companies seeking better sustainability performance are pushing forward the capacity of their production systems and supply chain towards more customized products, while keeping efficiency. It can also be seen from the case studies that besides the large body of literature dealing with mass customization and sustainability, it is still difficult for many companies to deploy these strategies at operational level. Therefore, operational frameworks and technical tools are needed to translate strategies regarding sustainability and/or mass customization into concrete initiatives. The tools provided within section 3 are only an example of what can be used for such purpose. This can also explain that, according to Pourabdollahian et al. (2014), industrials do not recognise any synergies between mass customization and sustainability.

As a matter of fact, mutual impacts between these paradigms require further investigation. See for instance the link between customer involvement and design for sustainability. Design for sustainability, or the co-design alone, is not enough to direct the enterprise towards sustainability. The assessment of different design alternatives and customer choices is mandatory. This research direction can benefit from existing works and frameworks for the assessment of sustainability and mass customization performance such as Boër et al. (2013), Nielsen et al. (2014), and Storbjerg et al. (2014).

The limited number of the case companies in this research is partly due to the relatively huge amount of data needed to apply the method and the time consuming modelling process. Moreover, we assume that even with three case companies, the analysis elucidates several issues such as, barriers of sustainability and mass customization (i.e. lack of operational frameworks) and open questions about synergies between sustainability and mass customization (e.g. customer co-design and eco-design). Moreover the case studies presented in the paper allows focusing not only on strategies but also on operational level. In order to address shortcomings of the limited number of case studies one can use questionnaire surveys. These generally lead to more conclusive analysis. However, an important point in using questionnaires is how to combine technical tools with strategic enablers in order to have a global vision coupling both strategic and operational levels, often addressed in silos.

\section{Conclusions and prospects}

This paper provides an overview of mass customization impact on sustainability. Several sustainability and mass customization enablers are identified out of a literature review. This latter showed that there is still no consensus on mass customization impact on sustainability. This mainly pertains to the lack of assessment frameworks and tools for deploying sustainability and mass customization at the operational levels within companies. The three case studies illustrates how enablers are deployed at the operational level and shows that often, companies seeking for more sustainability also strive to improve mass customization performance. Looking for a consensus about the relationships between these paradigms seems to be premature, as there are still a lot of open issues regarding their mutual impacts. One interesting research avenue seems to analyse the sustainability impact of specific mass customization enablers/aspects, such a product variety, customer order decoupling point and supply chain design.

\section{References}

Al Odeh M. and Smallwood J., 2012. Sustainable supply chain management: Literature review, trends, and framework. International Journal of Computational Engineering \& Management, Vol. 15, No. 1, pp. 2230 - 7893.

Bettoni A., Corti D., Canetta L., Taisch M. and P Pedrazzoli P., 2013. Integrated product and supply chain design: bridging the gap towards networked environment for effective implementation of a sustainable mass customized solution. International Journal of Engineering, Science and Technology, Vol. 5, No. 2, pp. 65-78.

Boër C.R., Pedrazzoli P., Bettoni A. and Sorlini M., 2013. Sustainability Assessment Model. In: Mass Customization and Sustainability, Bö̈r, C.R., Pedrazzoli, P., Bettoni, A., Sorlini (Eds.), pp. 33-142, Springer : London.

Blecker T., Abdelkafi N., Kaluza B. and Friedrich G., 2006. Controlling variety-induced complexity in mass customisation: a key metrics-based approach. International Journal of Mass Customization, Vol. 1, No. 2/3, pp. $272-298$.

Brunoe, T.D., Nielsen, K., Taps S.B. and Jørgensen K.A.2014. Sustainability evaluation of mass customization. In: Proc. of IFIP WG 5.7 International Conference - Advances in Production Management Systems (APMS 2013), Springer: Pennsylvania, USA.

Carter C.R. and Carter J.R. 1998. Interorganizational determinants of environmental purchasing : Initial evidence from the consumer products industries. Decision Sciences, Vol. 29, No. 3, pp. 659-684. 
Chopra S. and Meindl P. 2007. Supply Chain Management, Strategy, Planning, \& Operation. Pearson Education, Inc., New Jersey.

Cross R., Seidel R., Seidel M. and Shahbazpour M., 2009. Design communication for mass customisation. International Journal of Mass Customisation, Vol. 3, No. 2, pp. 146-164.

Daaboul J., Da Cunha C., Bernard A. and Laroche F., 2011. Design for mass customization: Product variety vs. process variety. CIRP Annals - Manufacturing Technology, Vol. 60, No. 1, pp. 169-174.

Da Silveira, G., Borenstein D. and Fogliatto F.S., 2001. Mass customization: literature review and research directions." International Journal of Production Economics, Vol. 72, No. 1, pp. 1-13.

Davis S. 1987. Future Perfect. England: Addison Wesley Longman.

Dietrich A.J., Kirn S. and Timm I.J., 2006. Implications of mass customization on business information systems." International Journal of Mass Customization, Vol. 1, No. 2/3, pp. 218 - 236.

Dreyer L.K., Hauschild M.Z. and Schierbeck J., 2010. Characterisation of social impacts in LCA. Part 1: Development of indicators for labour rights. International Journal of Life Cycle Assessment, Vol. 15, No. 3, pp. $247-259$.

Duray R., 2006. Pursuing capabilities of flexibility and quality: financial performance implications for mass customizers. International Journal of Mass Customisation, Vol. 1, No. 2/3, pp. $260-271$.

Elkington J., 1997. Cannibals With Forks: The Triple Bottom Line of 21st Century Business. Journal of Business Ethics, Vol. 23, No. 2, pp. 229-231.

National Institute of Standards and Technology (NIST), 1993. Announcing the Standard for Integration Definition for Function modelling. Federal Information Processing Standards Publication 183. Online, accessible from: http://www.idef.com/pdf/idef0.pdf.

Fogliatto F.S., Da Silveira, G. and Borenstein D., 2012. The mass customization decade: An updated review of the literature. International Journal of Production Economics, Vol. 138, No. 1, pp. 14-25.

Fortes J., 2009. Green supply chain management : A literature review. Otago Management Graduate Review, Vol. 7, No. 1, pp. 51-62..

Garbie I.H., 2013. DFSME: design for sustainable manufacturing enterprises (an economic viewpoint). International Journal of Production Research, Vol. 51, No. 2, pp. 479-503.

Gunasekaran A. and Spalanzani A., 2011. Sustainability of manufacturing and services: Investigations for research and applications. International Journal of Production Economics, Vol. 47, No. 1, pp. 99-111.

Jayal A.D., Badurdeen F., Dillon O.W. and Jawahir, Jr.I.S., 2010. Sustainable manufacturing: Modelling and optimization challenges at the product, process and system levels. CIRP Journal of Manufacturing Science and Technology, Vol. 2, No. 3, pp. 144-152.

Jiao J., Huang G.G.Q. and Tseng M. M., 2004. Concurrent enterprising for mass customization. Concurrent Engineering: Research and Application, Vol. 12, No. 2, pp. 83-88.

Jiao J., Simpson T.W. and Siddique Z., 2007. Product family design and platform-based product development: a state-of-the-art review. International Journal of Intelligent Manufacturing, Vol. 18, No. 1, pp. 5-29.

Jovane F., Yoshikawa H., Alting L., Boër C.R., Westkamper E., Williams D., Tseng M.M., Seliger G. and Paci A.M., 2008. The incoming global technological and industrial revolution towards competitive sustainable manufacturing. CIRP Annals Manufacturing Technology, Vol. 57, No. 2, pp. 641-659.

Kleindorfer P.R., Singhal K. and Van Wassenhove L.N., 2005. Sustainable operations management. Production and Operations Management, Vol. 14, No. 4, pp. 482-492.

Knight P., and Jenkins J.O., 2009. Adopting and applying eco-design techniques: a practitioners perspective. Journal of Cleaner Production, Vol. 17, No. 5, pp. 549-558.

Krikke H., Bloemhof-Ruwaard J. and Van Wassenhove L.N., 2003. Concurrent product and closed-loop supply chain design with an application to refrigerators. International Journal of Production Research, Vol. 41, No. 6, pp. 3689-3719.

Large R.O. and Thomsen C.G. 2011. Drivers of green supply management performance: Evidence from Germany. Journal of Purchasing and Supply Management, Vol. 17, No. 3, pp. 176-184.

Le Duigou J., Bernard A. and Perry N., 2011. Framework for Product Lifecycle Management integration in Small and Medium Enterprises networks. Computer-Aided Design \& Applications, Vol. 8, No. 4, pp. 531-544.

Mortimer J., 2007. BMW creates production "triangle" in the UK to manufacture the new Mini. Industrial Robot: An International Journal, Vol. 34, No. 1, pp. $26-31$.

Medini K., Da Cunha C. and Bernard A., 2012. Sustainable mass customized enterprise: key concepts, enablers and assessment techniques. In: 14th IFAC Symposium on Information Control Problems in Manufacturing (pp. 522-527), Bucharest: International Federation of Automatic Control.

Meyer M. and Lehnerd A.P., 1997. The Power of Product Platform - Building Value and Cost Leadership. New York: Free Press.

Nielsen K., Brunoe T.D., Jorgensen K.A, and Taps S.B., 2014. Mass Customization Measurements Metrics. In: Proc. of the 7th World Conference on Mass Customization, Personalization, and Co-Creation (MCPC 2014), Springer: Aalborg, Denmark.

Pine B.J., 1993. Mass customization: The new frontier in business competition, Boston: Harvard Business School Press. 
Pourabdollahian G., Taisch M. and Piller F.T., 2014. Is Sustainable mass customization an oxymoron? an empirical study to analyze the environmental impacts of a MC business model.". In: Proc. of the 7th World Conference on Mass Customization, Personalization, and Co-Creation (MCPC 2014), Springer: Aalborg, Denmark.

Qiao G., Lu R.F. and McLean C., 2006. Flexible manufacturing systems for mass customisation manufacturing. International Journal of Mass Customisation, Vol. 1, No. 2/3, pp. 374-393.

Roach G.M., Cox J. and Sorensen C.D., 2011. The product design generator: a system for producing design variants. International Journal of Mass Customisation, Vol. 1, No. 1, pp. 83-106.

S-MC-S consortium, 2011. S-MC-S - D0.1 M18 Progress Report, Switzerland: European Commission.

Selladurai R.S., 2004. Mass customization in operations management: oxymoron or reality? Omega, Vol. 32, No. 4, pp. 295-300.

Shahzad M. K. and Hadj-Hamou K., 2013. Integrated supply chain and product family architecture under highly customized demand. Journal of Intelligent Manufacturing, Vol. 24, No. 5, pp. 1005-1018.

Sievaanen M. and Peltonen L.2006. Mass customising footwear: the left ${ }^{\circledR}$ foot company case. International Journal of Mass Customisation, Vol. 1, No. 4, pp. $480-491$.

Smith S., Smith G.C., Jiao R. and Chu C.H., 2013. Mass customization in the product life cycle. Journal of Intelligent Manufacturing, Vol. 24, No. 5, pp. 877-885.

Storbjerg, S.H., Brunoe T.D., and Nielsen K., 2014. Mass customization and performance assessment: overview and research directions. In: Proc. of the 7th World Conference on Mass Customization, Per-sonalization, and Co-Creation (MCPC 2014), Springer: Aalborg, Denmark.

Tseng M.M., Jiao R.., and Merchant E., 1996. Design for mass customization. CIRP Annals - Manufacturing Technology, Vol. 45, No. 1, pp. 153-156.

Tseng M.M. and Jiao R., 2001. Mass Customization, Handbook of Industrial Engineering, New York: Wiley.

Tseng M.M. and Piller F., 2003. The Customer Centric Enterprise. In: Tseng, M.M., and F. Piller (Eds.), The Customer Centric Enterprise - Advances in Mass Customization and Personalization (pp. 3-16), Berlin: Springer.

United Nations Environment Programme (UNEP) and Society of Environmental Toxicology and Chemistry (SETAC), 2009. Life Cycle Management How business uses it to decrease footprint, create opportunities and make value chains more sustainable, Ireland: Power Editing. Online, accessible from: http://www.unep.fr/shared/publications/pdf/DTIx1208xPALifeCycleApproach-Howbusinessusesit.pdf. .

World Commission on Environment and Development (WCED), 1987. Our Common Future, Oxford USA: University Press.

\section{Acknowledgement}

This work has been partly funded by the European Commission through S-MC-S (Sustainable Mass Customization - Mass Customization for Sustainability) project (Grant Agreement No: FoF.NMP.2010-2260090 - S-MC-S).

\section{Biographical notes}

Khaled Medini is currently an Assistant Professor in Industrial Engineering at Ecole Nationale Supérieure des Mines de Saint Etienne, France. He received his $\mathrm{PhD}$ from the Ecole Centrale de Nantes, France in 2013. He holds a MSc of Industrial Engineering from the Ecole Centrale de Lille, 2010 and an Engineer Diploma from Ecole Nationale d'Ingénieurs de Tunis, 2009. His research interests are performance evaluation, supply chain management, enterprise modelling and simulation, sustainability, product services systems and mass customization

Julien Le Duigou is an Associate Professor at Université de Technologie de Compiègne, France. He obtained his MSc in Mechatronics and a Mechanical Engineering Degree at Supmeca in 2006 and received a Ph.D. in Mechanical Engineering from Ecole Centrale de Nantes in 2010. Currently, his research interests include Product Lifecycle Management, Product/Process integration and Interoperability.

Catherine Da Cunha is an Associate Professor in Industrial Engineering at the École Centrale de Nantes, France. She received her Ph.D from the INP Grenoble, France in 2004. Her main interests are in the area of information use within the firm, in the production as well as in the organizational field. She is particularly interested in the potential of partial or unmature information for Mass Customisation.

Prof. A. Bernard, 55, graduated in 82, PhD in 89, was associate-Professor, from 90 to 96 in Centrale Paris. From Sept. 96 to Oct. 01 , he was Professor in CRAN, Nancy I, in the "Integrated Design and Manufacturing" team. Since 0ct. 01, he has been Professor at Centrale Nantes and Dean for Research from 07 to 12. He is researcher in IRCCyN laboratory (UMR CNRS 6597) in the "Systems Engineering -Products-Performances-Perceptions" team. His research topics are KM, PLM, information system modeling, interoperability, human safety modeling and evaluation, enterprise modeling, systems performance evaluation, virtual engineering, additive manufacturing, reverse engineering. He supervised $25 \mathrm{PhD}$ students, recently on extended enterprise modeling, simulation and performance evaluation. He published more than 250 papers in refereed international journals, books and conferences. He is vice-chairman of WG5.1 of IFIP (Global Product Development for the whole product lifecycle) and chairman of CIRP STC Design.

Received June 2014

Accepted August 2014

Final acceptance in revised form September 2014 